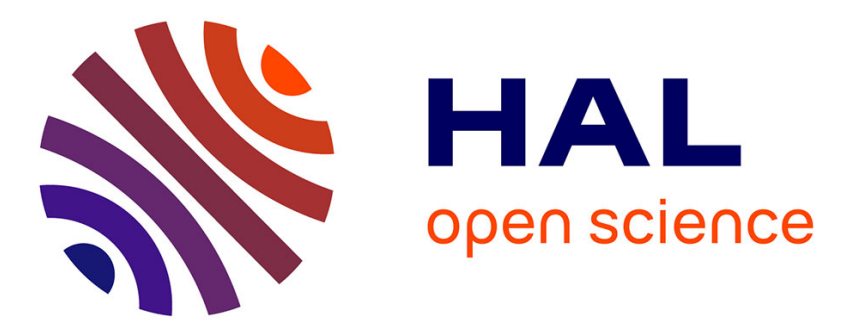

\title{
Carbon coatings on optical fibres by PECVD
}

V. Verbrugge, L. Segers, R. Winand, M. Charasse, C. Quinty, J. Le Pesant

\section{To cite this version:}

V. Verbrugge, L. Segers, R. Winand, M. Charasse, C. Quinty, et al.. Carbon coatings on optical fibres by PECVD. Journal de Physique IV Proceedings, 1993, 03 (C7), pp.C7-1377-C7-1382.

10.1051/jp4:19937210 . jpa-00251845

\section{HAL Id: jpa-00251845 https://hal.science/jpa-00251845}

Submitted on 1 Jan 1993

HAL is a multi-disciplinary open access archive for the deposit and dissemination of scientific research documents, whether they are published or not. The documents may come from teaching and research institutions in France or abroad, or from public or private research centers.
L'archive ouverte pluridisciplinaire HAL, est destinée au dépôt et à la diffusion de documents scientifiques de niveau recherche, publiés ou non, émanant des établissements d'enseignement et de recherche français ou étrangers, des laboratoires publics ou privés. 


\title{
Carbon coatings on optical fibres by PECVD
}

\author{
V. VERBRUGGE, L. SEGERS, R. WINAND, M.N. CHARASSE* , C. QUINTY* and
} J.P. LE PESANT*

Service Métallurgie-Electrochimie Cp 165, Université Libre de Bruxelles, 50 Av F.D. Roosevelt, 1050 Bruxelles, Belgium

* THOMSON CSF, Laboratoire Central de Recherche, Domaine de Corbeville, 91404 Orsay, France

\section{$\underline{\text { Abstract }}$}

An RF plasma CVD equipment was built for carbon coating on moving optical fibres. The effects of process parameters and gas composition on coating properties and deposition rate were investigated. Finally best results were obtained with $\mathrm{C}_{2} \mathrm{H}_{2}-\mathrm{Ar}$ plasmas. Homogeneous deposits could be obtained with a typical growth rate of $50 \mathrm{~nm} / \mathrm{s}$ at fibre drawing speeds up to $2 \mathrm{~m} / \mathrm{s}$.

\section{1) Introduction}

The limitation of the life time of silica optical fibres comes from the action of the humidity; it creates microcracks which propagate inside the fibre, especially when the fibre is tightly wound or subjected to mechanical stresses, like in the optical fibre sensor applications. The standard epoxyacrylate coating is not completely hermetic, and is damaged at temperatures higher than $60^{\circ} \mathrm{C}$. Therefore, there is a need for hermetic and high temperature coatings for silica optical fibres.

For this purpose, a new RF plasma enhanced CVD technique, compatible with optical fibres drawing has been developped to make carbon hermetic coatings. For further on-line applications on an industrial drawing tower the deposition rate has to be compatible with the drawing speed which is typically of the order of $2 \mathrm{~m} / \mathrm{s}$. Therefore, the authors consider that a deposition rate of at least $5 \mathrm{~nm} / \mathrm{s}$ is required to fulfil the objective.

\section{2) Experimental equipment}

Taking into account the cylindrical shape of the fibres, an inductive R.F. plasma technique was chosen to guarantee cylindrical homogeneity of the coating and to avoid any electrodes contamination.

The equipment for the coating of moving fibres is represented on figure $\mathrm{n}^{\circ} 1$. The reactor consists of a quartz tube surrounded by the $R F$ coil and connected to a vacuum unit. 


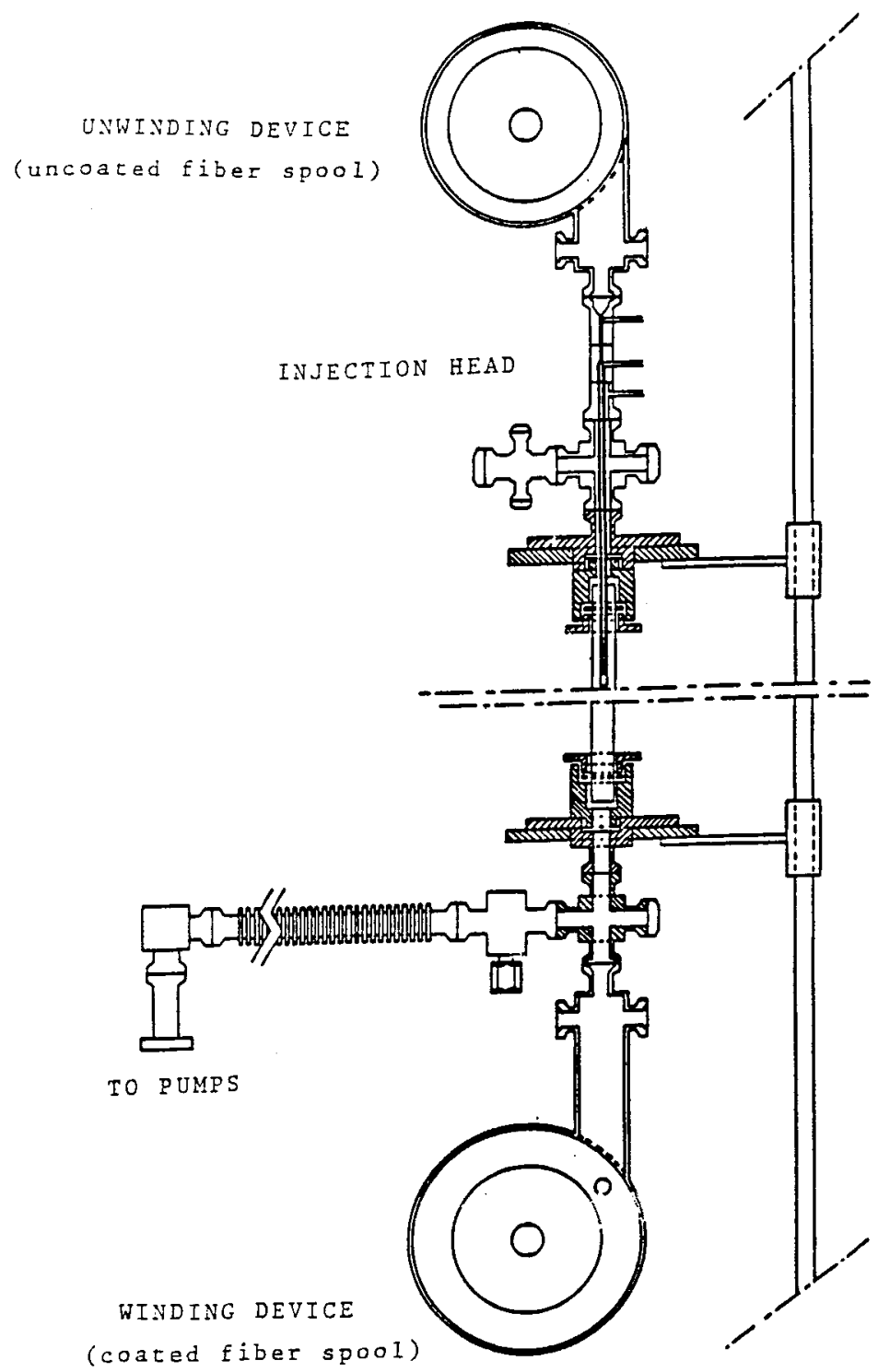

Fig. ${ }^{\circ} 1:$

Schematic view of the PECVD reactor. 
A winding-unwinding device consists of two vacuum tanks allowing bare fibres placed in the upper tank to pass through the plasma where the coating process occurs. Coated fibres are then recoiled in the lower tank. Dedicated electronic devices and motor units allow to control and limit mechanical forces on the fibre during the process. Maximum fibre speed is of the order of $2 \mathrm{~m} / \mathrm{s}$. Reactive and plasma gases are introduced by means of a specially designed injection head.

The same reactor with a simple injection head and various sample holders was first used to coat samples of the same chemical nature than optical fibres (pure silica) but with other shapes like plates or rods to facilitate thickness measurements and coating characterization.

\section{3) Results}

Experiments were performed with various plasma gas composition and process conditions in order to obtain coatings of good quality at a high deposition rate.

\section{1) Experiments with $\mathrm{CH}_{4}$}

The first coatings were realized with $\mathrm{CH}_{4}-\mathrm{H}_{2}$ plasmas which provide homogeneous and good quality films. But the deposition rate was too low: 0.01 $\mathrm{nm} / \mathrm{s}$.

Suspecting that hydrogen could reduce the growth rate, further experiments were performed in pure $\mathrm{CH}_{4}$ plasmas. At high $\mathrm{CH}_{4}$ flow rates ( $>6$ sccm) and high pressures ( $>3$ mbars) only black and powdery deposits were observed. By reducing those values, adherent homogeneous films were obtained. Typicall process conditions were: RF power: 120 watts ; $\mathrm{CH}_{4}$ pressure: $10-2$ mbar.

Investigations of the films by AUGER electron spectroscopy analyses showed the presence of $\mathrm{C}, \mathrm{Si}$ and $\mathrm{O}$, without contamination. XPS analyses revealed a low silicon content in the carbon film and a single carbon peak; SEM observations showed that the films are of good quality in terms of homogeneity and morphology.

Fourier tranform infra-red (FTIR) and RAMAN spectroscopy analyses were carried out for further characterization of the films. To avoid IR interferences with the silica substrate,the films analysed by the FTIR method have been grown on Ge discs. From those analyses, it has been found that $\mathrm{sp}^{2}$ and $\mathrm{sp}^{3}$ carbon bonds are present, with a sensible amount of hydrogen. The $\mathrm{sp}^{2} / \mathrm{sp}^{3}$ ratio is close to 0.5. RAMAN and X-ray analyses indicate that carbon in the film is amorphous.

Despite good film quality, the deposition process with $\mathrm{CH} 4$ was abandonned due to low deposition rate (less than $0.03 \mathrm{~nm} / \mathrm{s}$ ) as determined with a DEKTAK profilometer 3030 on flat substrates. 


\section{2) Experiments with $\mathrm{C} 2 \mathrm{H} 2$}

In order to increase the deposition rate and according to specific properties of acetylen, experiments were performed in pure $\mathrm{C} 2 \mathrm{H} 2$ plasmas. It could immediately be observed that the growing rate is very fast but the plasma is difficult to stabilize. Argon with a partial pressure between 0.1 and 0.2 mbars was therefore added to ensure a good stability of the process.

Because of $\mathrm{C} 2 \mathrm{H} 2$ high reactivity, its flow rate could be increasec to 5 sccm while the injected power could be reduced (usually between 36 and 96 watts) as compared with coating realized from $\mathrm{CH} 4$ plasmas. On that account the samples are submitted to less heating and hence to less thermal stresses.

At this stage of the research, the main objectice was to obtain high deposition rates compatible with fibre drawing speeds. Moreover it was observed that generally speaking deposition rates were higher on small cylindrical substrates than on plates. Therefore experiments with $\mathrm{C} 2 \mathrm{H} 2-\mathrm{Ar}$ were performed on small rods and static or moving optical fibres. As a consequence, the characterization techniques used previsiously could no longer be used. However homogeneity, absence of cracks and porosity could be observed by SEM.

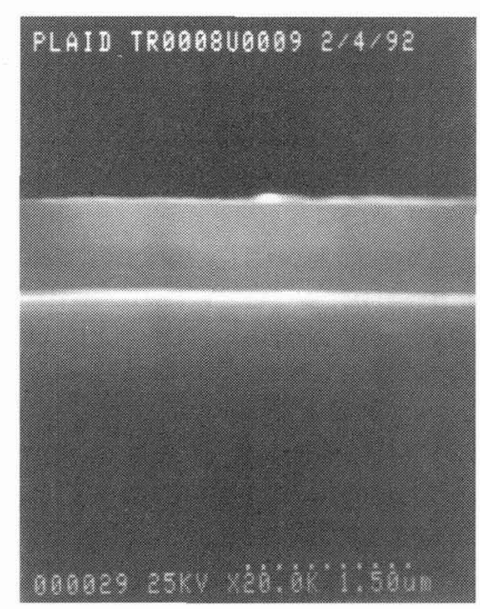

Fig. $n^{\circ}$ :

SEM picture of a cleaved rod.The measured thickness is $0.8 \mu \mathrm{m}$ $\left(2 \mathrm{~min}\right.$ at 36 watts; 5 sccm $\mathrm{C}_{2} \mathrm{H}_{2} ; 0.2 \mathrm{mbar} \mathrm{Ar}$ ). 
A new procedure for thickness measurements of carbon coatings made on small cylindrical samples has been set up. It consists in cleaving the rod (or the fibre) and observing the cross section by SEM. Figure 2 shows the typical picture obtained by this method on a coated rod allowing thickness determination. Moreover it shows the perfect homogeneity of the film.

The deposition rate was investigated using this thickness measurement technique for various process conditions. Typical curves are shown on figure $\mathrm{n}^{\circ} 3$ on rods.

thickness $(\mu \mathrm{m})$

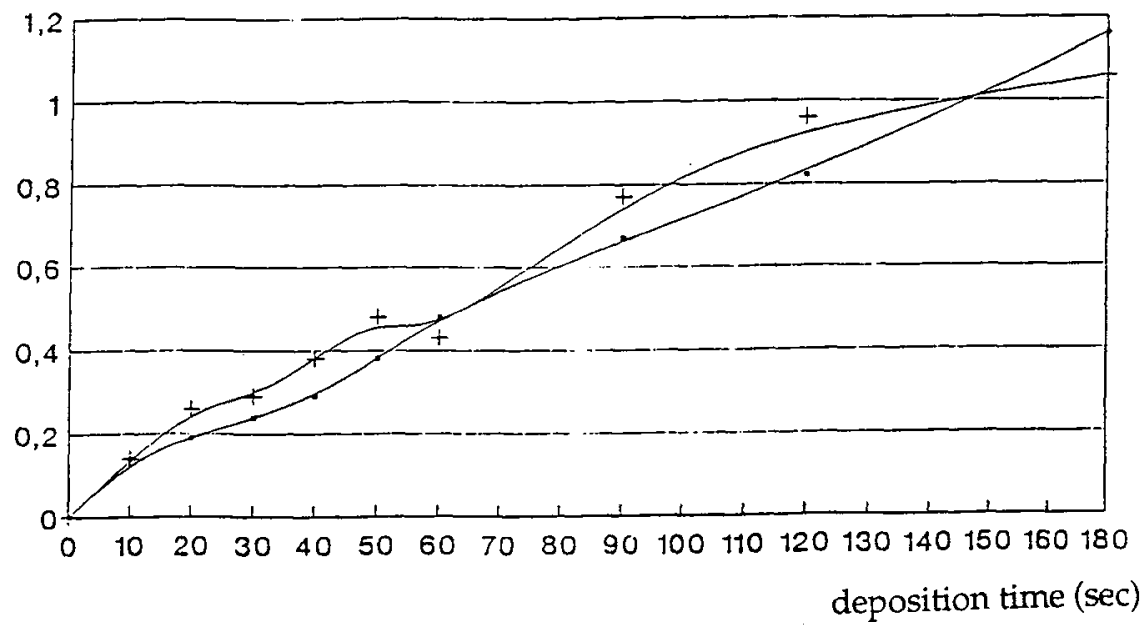

Fig. $n^{\circ} 3$ :

Evolution of coating thickness versus deposition time for two different plasma characteristics:

1) 0.1 mbar $\mathrm{Ar} ; 48$ watts

+) 0.2 mbar $\mathrm{Ar} ; 36$ watts.

As the results on static fibres were very promising experiments were realized on moving fibres at different drawing speed (example of the morphology of the coating on an optical fibre can be seen on figure $n^{\circ} 4$ ). Batches of $50 \mathrm{~m}$ were necessary to allow mechanical tests and several hundreds of meters of optical fibres have thus already been coated with different experimental conditions. Typical process conditions are as follows: Ar partial pressure: 0.2 mbar; $\mathrm{RF}$ power: 72 watts; $\mathrm{C}_{2} \mathrm{H}_{2}$ flow rate: $5 \mathrm{sccm}$. Mechanical tests are presently under progress. 


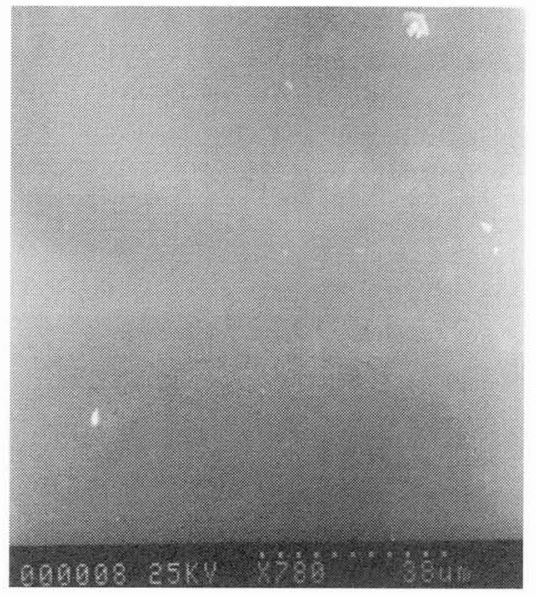

Fig. $n^{\circ} 4:$

SEM observation of the morphology of the carbon coating on an optical fibre (power: 36 watts; $\mathrm{PAr}: 0.2$ mbar: $\mathrm{C}_{2} \mathrm{H}_{2}$ flow rate: $5 \mathrm{sccm}$ )

Deposition speeds of the order of magnitude of $50 \mathrm{~nm} / \mathrm{s}$ can easily be reached on optical fibres and are compatible with the industrial drawing speeds of the fibres. Moreover the R.F. coil has been lengthened from 4 up to $20 \mathrm{~cm}$ without any problem. This allows to increase the residence time of the fibre in the plasma and thus the thickness of the carbon film. If needed the length of the coil and thus of the plasma could be further increased in order to perfectly fulfil the industrial process requirements.

\section{4) Conclusion}

From the results obtained so far, it can be concluded that carbon films can be grown on optical fibres with a deposition rate of $50 \mathrm{~nm} / \mathrm{s}$, compatible with an industrial drawing tower application. The inductive R.F. plasma is perfectly suited for cylindrical samples coating and ensures a good homogeneity of the coating all around the fibre.

This work was supported in part by EEC under contract BRITE-EURAM nBREU-0116. 